\title{
Research on the international nuclear market markets based on customers' perspective
}

\author{
Ke WU \\ China nuclear power engineering company ,Shenzhen, China \\ cyperpunk@163.com
}

\begin{abstract}
Keywords: customer' demand ,international nuclear markets, emerging markets ,case study
\end{abstract} Abstract: Through analyzing the recent international nuclear power tender cases, summarize the new features of the markets and the divers demand of the customers. Remind China nuclear power cooperation to pay more attention to the demands of customer

\section{The rise of the emerging markets}

Emerging markets playing a more important role in world nuclear markets.Affected by the Fukushima nuclear accident, the development of world nuclear power has experienced a period of sluggish. After the accident, the established nuclear power markets, such as Europe and the United States have improved nuclear safety requirements for both operational reactors and the approval of new reactors, resulting in a significant decline in the demand for new nuclear power units. Until last two years, the nuclear power markets have a sign of revive, but the safety requirements for new licenses have become more stringent.

In recent years, it seems that the nuclear has come to a "renaissance". Concerns about climate change, security of supply, and depleting fossil fuel reserves have spurred a revival of interest in nuclear power generation in Europe and North America, while other regions continue or initiate an expansion. Yet today, a nuclear renaissance is underway, and globally 65 reactors are under construction .[1] In 2011, the United States restarted the new reactor projects after the March 1979 Three Mile Island accident . The United Kingdom also embarked on the first nuclear power plant for more than 20 years. And more and more countries without any nuclear experiences embark on the deployment of the nuclear reactors. With fast growing energy needs, the emerging markets become main markets of the nuclear power .

In one aspect, Changes in customers have brought different and diverse demands .Customers from emerging markets are no longer satisfied with the single scheme offered by the bidder. Their diverse demands such as financial solutions, technician training and other requirements are actually in need of package solutions. Other aspect, due to the drastic market competition, although standard nuclear design assessments program have not yet established, customers from the emerging markets still set technical threshold for the technology. After the Fukushima nuclear accident, the usage of Generation III nuclear power technology is the most basic requirement in the market.

\section{Drastic market competition}

The tightening domestic markets cause the established nuclear power countries such as France, the United States, Japan to expand their nuclear business overseas. And to control the markets they set stricter standards by virtue of experiences and market recognition, which greatly enhances the access threshold for the new competitors. While emerging rivals, such as South Korea, with a contract to provide four commercial nuclear reactors to the United Arab Emirates (UAE), are signaling a new role for the South Korea in the world nuclear energy market. But it is important to note that South Korea won the UAE project on the basis of that the APR1400 has already been built domestically, and it also has applied the Design Certification Application Review of the Nuclear Regulatory Commission (NRC).

\section{Summary}

Customers in the goblal nuclear power markets have changed. The competition is extremely fierce. That is the international nuclear power market we are facing. In this market, earlier entrants have 
obvious advantages. But the market is ultimately determined by the customers. If China want to participate in the competition, we must understand the customers demand at first.

\section{Case study on Generation III international bidding}

\section{The United Arab Emirates Nuclear Program}

The United Arab Emirates (UAE) has embarked on a program to build civilian nuclear power plants in 2009. The UAE hopes to become the first Gulf state to develop a civilian nuclear program to help meet soaring demand for power. The UAE has a clear nuclear power development plan, but no experience in nuclear means relatively weak nuclear in nuclear industry, limited in the regulatory capacity. In the UAE nuclear program, the regulatory authorities Emirates Nuclear Energy Corporation (ENEC) specifically, focused on five core criteria in reaching its final decision. [2]i)Safety : All three teams involved in the Prime Contractor Selection demonstrated that their technology and safety programs met the latest international standards.ii) Deliverability: A demonstrated ability to meet the ENEC program goals.iii)Contract Compliance: Conformance with ENEC's proposed "prime contractor "business structure.iv)Human Resource Development: A commitment to, and detailed planning for human resource development in the UAE.v) Commercial Competitiveness: A commercial proposal that promoted UAE economic competitiveness via the provision of low-cost electricity.

To win this one of the world's largest nuclear projects, South Korea made great efforts to demonstrate their ability in nuclear power. With full support of the South Korean government, they eventually beat French, US and Japanese rivals. The deal marks the first time South Korea will export its nuclear reactors. The key experience could be summarized as follows i)Operational performance and optimized construction period

South Korea's nuclear reactors have been rated at the top of key international performance indices. South Korea has taken great strides over the past 33 years since the country's first NPP went operational to develop technology which allows the safe and reliable production and distribution of nuclear power. And their excellent performances in the project duration control. [3]

ii ) Standard design certification and well going demonstration project

Although the APR1400 hasn't completed construction in South Korea when the UAE nuclear tender started, it has obtained the standard design approval from Nuclear Safety and Security Commission which is the regulation agency of South Korea. The first rector of APR1400 has already approved to start construction in South Korea. All these facts eventually acquire the UAE customers' recognition. iii)Package solutions

The capital cost of the nuclear programs is pretty high, with very large upfront costs and long project cycles which carry a large variety of risks. Customers who want to reduce risk often demand for financial solutions in the tender. That is exactly included in the competitive package solutions offered by South Korean consortium.

Being lack of the nuclear construction experience, UAE want to develop their own nuclear industry through the first nuclear program. Moreover they want the successful bidder to control and manage the whole process of the project. The solutions offered by South Korean consortium which mainly include building, operation \& maintenance, fuel supply, technical training and technology transfer, just satisfy the demand in UAE.

iv ) One Team

APR1400 technology derives from the U.S nuclear technology, which means that South Korea is subject to U.S. export control requirements .To avoid the restriction, South Korea government persuade the U.S. congress to permit the peaceful usage of nuclear energy agreement with UAE and agree the export of four APR1400 units through conducting public relations.[4]

The thirty years experience of nuclear industry formed the nuclear alliance leaded by KEPCO ( Korea Electric Power Corporation ) which covers the whole industry of nuclear power engineering 
project from design, construction, equipment, fuel supply, operation and maintenance. In the competition of UAE program, the alliance not only involves the Korean bank company to offer financial solution but also involves local companies specialize in cable and steel of UAE and American companies.

v ) The competitive price

The Korean consortium was selected over two other proposals, from AREVA and General

Electric-Hitachi. According to media reports, the decision was strongly affected by price. One report indicated that the KEPCO total of \$20 billion was 30\% lower than the AREVA bid, which in turn was lower than the GE-Hitachi offer. Another report described KEPCO's price as \$16 billion lower than AREVA's. [5]

\section{Turkey Nuclear Program}

In May 2013, Turkey's second nuclear power plant in Sinop started the tender program. Japanese consortium has presently set for the deal. However, a Japanese official said that despite Turkey's decision to award a Japanese-led consortium exclusive negotiating rights for the \$20bn-plus tender, there was still "a long way to go" regarding financial terms. France would also have a central role in the prospective deal. [6]

Turkey prepared for a second nuclear power plant with capacity of 5 million to 560 million kilowatts in Sinop since the beginning of February 2008. Groups from China, South Korea and Canada had all declared their interest in the project. At first Turkey gave the exclusive negotiating rights to South Korean consortium. But they withdrew the project after being refused to guarantee the electricity sales by Turkish government.

Chinese group CGN (China General Nuclear Power Corporation) expressed to absorb all the risk to establish themselves as nuclear exporters. However Turkey eventually chose the Japanese and French consortium. So why are they being chosen?

To prepare the bids, Japanese invited Mitsubishi Heavy Industries (MHI), AREVA, GDF-Suze and Itochu Corporation to form the Japanese-French consortium. This strong-strong combination with rich experiences and good reputation is the important reason to get the exclusive negotiation right. Similar to the South Korean consortium in UAE project, the Japanese consortium included the co-designer AREVE and MHI, the plant operator GDF-Suez and the experienced financial sponsor Itochu Corporation.

\section{Summary}

To satisfy the customers' diverse demand, the single corporation even supported by the government cannot compete with the consortium. The biding team should express

their strong comprehensive ablity to solve all customers' problem.

\section{Conclusion of the international customers demand}

Through the analysis of cases referred above, the competition in international nuclear power markets present new features due to the increased cost of the nuclear power :

i) Customers are more realistically focus on the balance between technology advancement and the cost. Many bidding cases have fully supported this point. The reactors with more economical feature like AES92, APR1400 are getting more shares around the world.

ii) The biding process of international nuclear program has become more complex. Customers often pick up one bidder to award the exclusive negotiate rights according to the technical criterion. They will mainly discuss the economic issues in the next round. If the two sides can't come to an agreement, customer seeks another bidder to start the process again. The key in the second round negotiation is about the electricity price, both sides want to maximally reduce their risks in the project.

iii)The new contract model like BOT(build-operation-transfer)、BOOT(build-operate-own-transfer) gradually become popular. Most of the emerging countries are developing country. Therefore they 
require suppliers to responsible for reactor operation and the construction funds. These two new contract models will mitigate the financial pressure of customers, ensure their interests.

The new features reflect the new demands of the customers. In conclusion, we can divide into all the demands into the general demand indicators and the individual demand indicators.(as shown in Fig.1)

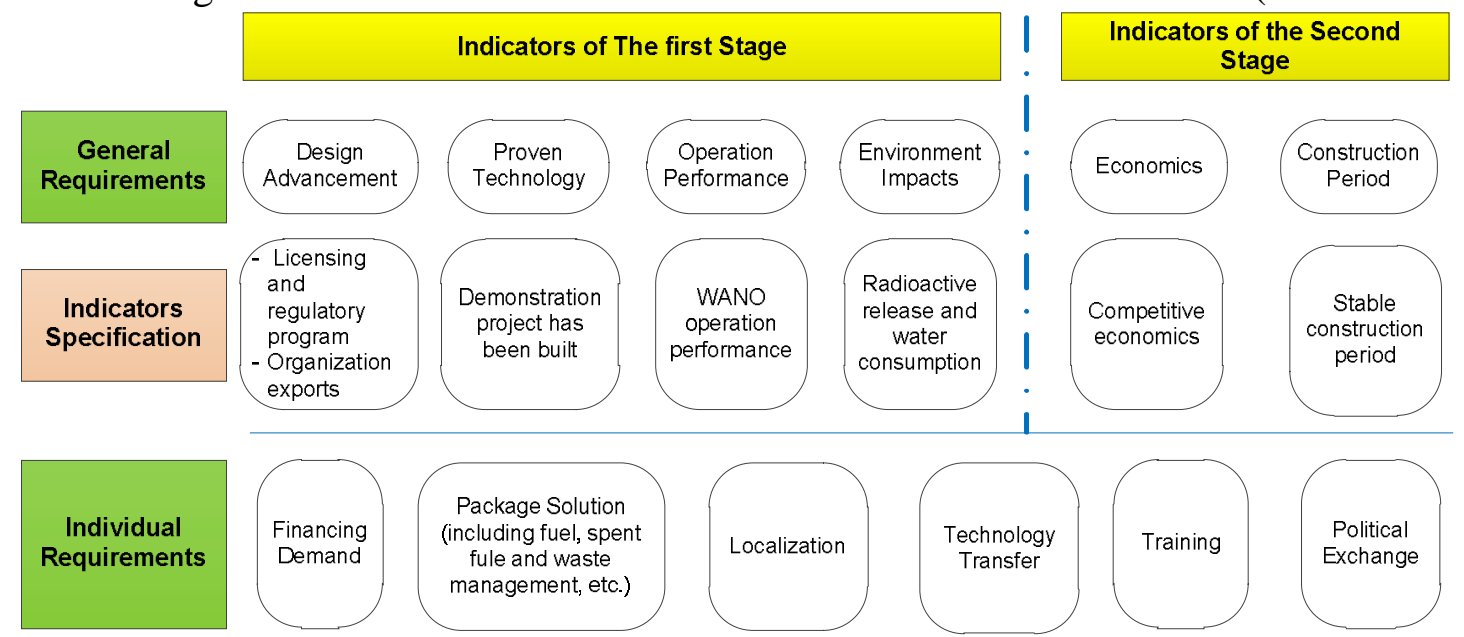

Figure 1: analysis of demands of international customers

\section{The Opportunity and challenge of Chinese nuclear power technology in global markets}

In recent global nuclear power market, two countries performed excellently. The Russian Federation national nuclear corporation ROSATOM still gets remarkable achievements especially after the Fukushima nuclear accident. The other country is South Korea. After the UAE project, it also reached nuclear collaboration with Finland, Qatar, Saudi Arabia and so on. In conclusion their achievements are ascribed to the compliance with the customers' demand. Only meet the diverse demands of customers, with core competencies, can win the bid. With the independent Generation III nuclear reactor, China also has the ability to compete in the global nuclear power markets. But before, we should pay attention to the customer.

\section{References}

[1] World Nuclear Power Reactors Uranium requirements www.world-nuclear.org/info/reactors.ht $\mathrm{ml}$

[2] Ahmed A. Namatalla, Gulf News, UAE, South Korea sign nuclear deal to build plants in the UAE (2009) http://gulfnews.com/business/sectors/general/uae-south-korea-sign-nuclear-deal-to-build-pla nts-in-the-uae- 1.558508

[3] 10 Reasons to Choose a KEPCO Reactor http://home.kepco.co.kr/kepco/EN/G/htmlView/ENG DHP001.do?menuCd=EN070501

[4] Christopher M. Blanchard, Paul K. Kerr The United Arab Emirates Nuclear Program and Propos ed U.S. Nuclear Cooperation ( 2010 ) fpc.state.gov/documents/organization/154163.pdf

[5] Chris Stanton, "Nuclear Bid to Be Industry Norm," The National, December 28, 2009, http://ww w.thenational.ae/apps/pbcs.dll/article?AID=/20091228/BUSINESS/712289928.

[6] Daniel Dombey, Jonathan Soble, Hugh Carnegy, Japanese consortium set for Turkish nuclear po wer deal(2013) http://www.ft.com/int1/cms/s/0/3c488e16-b33a-11e2-b5a5-00144feabdc0.html\#axzz4 3PstytSw 